\title{
VIII: FeLLOW TRAVELERS: LOCALISM, OCCIDENTALISM, AND ORIENTALISM
}

For nearly the whole route I did not depart from the devoted Mtkvari, you would think that the Mtkvari was also one of our fellow travelers! ${ }^{1}$

In his earliest travels in 1878, Bavreli finds himself two fellow travelers: a Russian chinovnik and the "devoted" Mtkvari River, which flows along their route. As fellow travelers, the Russian chinovnik (bureaucrat) and the Georgian river each stand as figures for imagined horizons against which Bavreli constitutes himself as a "traveler." Against these horizons the landscape they traverse comes to have very different, mutually unintelligible meanings. Like most of the Georgian travelers of his time, Bavreli is an ambivalent traveler, never traveling very far from "home." Accordingly, Bavreli defines his own travel as being local by providing himself with two kinds of fellow travelers: human and nonhuman. On the one hand, the extremely circumscribed space-time of his own travels are defined in opposition to the space-times that define the rather more cosmopolitan journeys of his human (Russian, Georgian, Armenian) fellow travelers, variously defined in terms of imperial service, military campaigns, or long-distance trade. On the other hand, Bavreli personifies the landscape of the locality itself, particularly the rivers, the Mtkvari and the Choroxi, which, after all, like him, travel, but always with respect to a concrete and determinate landscape. By emphasizing his difference from these cosmopolitan human fellow travelers and his kinship with his local nonhuman fellow travelers, Bavreli valorizes a specific form of travel, a travel that is circumscribed by locality and nature. This chapter seeks to locate this self-consciously Georgian form of travel and traveler in relation to other "European" forms of travel and fellow travelers against which Georgian travelers self-consciously defined themselves, as well as the different space-times in which Georgians traveled: localist travel within Georgia, archaeological travels into the Georgian past, Occidentalist travels into the European future, and finally, Bavreli's own Orientalist travels in Ottoman Georgia. 
We return to Bavreli's early travels by the banks of the Mtkvari. Even as Bavreli and the Russian chinovnik travel together through the same concrete landscape, they experience these places as being part of very different journeys. For his fellow traveler, this place, by the banks of the Mtkvari in Georgia, is simply one of many more or less equivalent places he might have been appointed, equivalent because they are far from the imperial metropole: "my fellow traveler had recently finished school and they had appointed him for service 'somewhere' [sadghac] and he was on his way to this 'somewhere' ..." The Russian traveler experiences "here" as a vague and indefinite "somewhere"; somewhere in an empire of more or less equivalent somewheres, somewhere where someone like him, whose travels form a career defined by his service to empire and the boundaries of that empire, has been sent to serve. The chinovnik is one of those Andersonian absolutist functionaries, whose travels, indeed whose life, is a career path that is defined at the intersection by algebraic variables of rank (chini) and place, producing senses of abstract equivalence between fellow travelers based on this very same algebra of rank and place:

Sent out to a township A at rank V, he may return to the capital at rank W; proceed to province B at rank X; continue to vice-royalty $C$ at rank $\mathrm{Y}$; and end his pilgrimage in the capital at rank $Z$.... The last thing the functionary wants is to return home for he has no home with any intrinsic value. And this: on his upward-spiralling road he encounters as eager fellow pilgrims his functionary colleagues, from places and families he has scarcely heard of and surely hopes never to have to see. But in experiencing them as travelling-companions, a consciousness of connectedness ('Why are we ... here ... together') emerges (Anderson 1991, 55-6)

But no such consciousness of connectedness is obtained between this chinovnik and Bavreli, who is not such a fellow variable within the abstract algebra of empire. In fact, it is precisely because of their differences that they value each other as fellow travelers. Bavreli admits to the reader that he is happy that his fellow traveler is chiniani ("having rank," that is, an official) since this will simplify his own travels consid- 
erably; the fact of the matter is that Bavreli lacks the funds necessary for travel. For his part, the chinovnik admits that he values Bavreli's company precisely because he is a "local" (akauri, one from "here"), who can explain aspects of the locality to him. ${ }^{2}$ For Bavreli, what the chinovnik experiences as a somewhat vague and indifferent "somewhere" is strongly centered as a familiar "here," near his home and his travels, for the most part, are in and around his home region. In fact, in these very "travel notes," Bavreli is "traveling" (if we can call it that) home, ${ }^{3}$ to the very village, Bavra, near Axalcixe, near the border with Ottoman Georgia, from which he takes his nom de plume, to his home, "in the house of a poor peasant." 4

On his journey on the Ottoman Georgian river Choroxi, too, Bavreli casts a sideward glance at the very different itineraries that separate him from his human fellow travelers-including a Georgian nobleman, an Armenian merchant, and a pair of Russian officers-even as he shares the same boat along the same river with them. In a manner that recalls Chavchavadze's alignment of himself with Lelt Ghunia, Bavreli aligns himself with the Ottoman boatman, who agrees to take him on the journey for a lesser rate of four rubles, because, as he says in his heavily Ottomanized Georgian, dutifully transcribed, as always, by Bavreli:

'bahli (diax [Yes]) I will take you. Hama (magram [but]) gurji (kartveli [Georgian]) ki (rom [if]) you were not, I would not have taken you at that bahat (pasat [price])] ${ }^{5}$

Despite the great difference between their dialects, the boatman's sense of a kind of kinship with a Gurji like Bavreli reflected concretely in the lower price of passage, in contrast with one of the other travelers, an Armenian merchant, who, as it turns out, must end up paying a higher-than-normal price. ${ }^{6}$ The Georgian nobleman and the Armenian merchant turn out to be old acquaintances, and Bavreli reports their overheard conversation at length. ${ }^{7}$ From characteristic details of dress, movement, down to the macaronic Russian-and-Armenian-inflected speech of the merchant, it becomes clear that these two are almost comic stereotypical representatives of their species, their presence pointing to very different itineraries, very different worlds of motivation that divide them even as they share the same boat. The Georgian nobleman, who served at the front at Kars, deep inside Ottoman Geor- 
gia, is returning home to Poti via Batumi. The Armenian merchant is going to Istanbul via Batumi. The Armenian merchant, who plays the role of comic sidekick to the Georgian nobleman, complains that his noble friend's journeys expanding the boundaries of empire are defined by a motivation of chini ("rank"), a motivation he does not understand, for his own extra-imperial travels are defined by money, he frankly admits: " $t$ 'o [Armenian-derived familiar address term] All you talk about is ranks (chini), tell me, did you make any money?" ${ }^{\text {Y }}$ Yet for all their differences, these two yet represent, like Bavreli, a kind of "local," in contrast to the other two travelers, Russian officers, one of whom is a dissolute drunk, with red eyes from loss of sleep from playing cards and drinking, a picture of absolute indifference to the journey which arbitrarily brings him to yet another arbitrary "somewhere" in the Russian Empire, and hence spends much of the journey playing cards with the other officer and the merchant. ${ }^{9}$ Each of these fellow travelers is an emissary from a different space-time, grounded in the horizons of different imaginaries and motivations, against which Bavreli can define himself as a "local" traveler.

Fellow travelers are defined not only by comparability of their conception of how the same or similar objective itinerary maps onto the wider phenomenological and motivational horizons of their travels ("spacetime"), but also by the comparability of their subjective aestheticized reactions to the landscape with those of other travelers. Along a welltraveled itinerary, such as the Dariel pass which everyone must cross who wishes to go from Russia to Georgia, one is never alone; there is no dearth of literary fellow travelers for a writer like Chavchavadze to keep him company. But Bavreli has no literary fellow travelers with whom to share his aesthetic appreciation of the sublime, the picturesque, and the beautiful in the landscape, he only has his Russian chinovnik, and there is nothing comparable in the thoughts of these two. Enraptured by the natural landscape along the banks of the Mtkvari River, Bavreli imagines another traveler, who is also a painter, who, however rushed he might be, still he would tarry involuntarily to paint the landscape on paper:

—imagine an isle, which divides the Mtkvari in two, a bridge crosses one branch of the Mtkvari from the bank to the isle, between whose abutments the Mtkvari runs seething with foam; a little further there is an old fort on a high cliff, to the right a village spreads out, a pretty 
forest and gardens, wild plum trees blooming with new flowers like white cotton and many similar decorations of nature. But oh! I, unfortunate one, where can I, with my weak pen, describe the beauty of my motherland! $!^{10}$

But his reverie is interrupted by his actual fellow traveler, the chinovnik, who raises his voice to scatter his "sweet thoughts," which turn on speculations about the quantity and type of game animals that can be found in the local forests.

The two travelers share the same road, even the same cart, but their minds are in different worlds. In contrast to the Russian chinovnik, Bavreli's private thoughts and nature seem in harmony, a harmony which is figured by the Mtkvari River, who had been until just now merely a salient feature of the natural landscape along the route, but now becomes an anthropomorphized, yet inarticulate fellow traveler, a familiar old acquaintance from his youth, whose mood here, however, has changed; here the river is unfamiliar, troubled, and angry:

What my fellow traveler was thinking, where his thoughts were running to, I do not know even now; mine however were flying very far and to such a place, for which I would sacrifice my whole youth for this moment; if only this thought and dream were to come true, I would have considered myself the most blessed of beings. . . . The cooing of the Mtkvari led us from temporary sleep. Oh how it made me happy, when I saw my old acquaintance and friend, the Mtkvari! It made me happy, but what to do, because this no longer was that Mtkvari, which I had seen in my boyhood-It now longer seemed to have that purity, that freshness, that peacefulness. The agitated Mtkvari was running along so angrily and so wrathfully grumbled, that my heart almost broke. That is the matter and misfortune, that I couldn't understand and do not know, what was the reason for its trouble.... I asked its beautiful banks 'why, why is it so angry?' - There was no one to answer. ${ }^{11}$

The Mtkvari moves from being a stable aesthetic figure connecting 
the natural beauty of the landscape along the journey, to an anthropomorphic figure, a moody and inarticulate fellow traveler. The Mtkvari is also a literary intertextual figure, allowing Bavreli to compare his travels here beside the Mtkvari to literary travelers like Chavchavadze elsewhere beside the Terek. Like the Terek for Chavchavadze, the anthropomorphic Mtkvari as fellow traveler stands for Bavreli's own organic connection as local and intelligent to the landscape and by extension, its people (in contrast to the official, who represents a competing field of imperial elites for the local intelligentsia). This is the same Mtkvari which Bavreli elsewhere (above) contrasts to the Choroxi, a semifabulous river which has become unfamiliar, and speaks in a strange, foreign accented voice, a figure for Ottoman Georgia, a river which is pictured as saying farewell to the familiar cliffs of its headwaters as it heads away into Ottoman Georgia, much as the population of Ottoman Georgia are leaving their homes en masse fleeing the Russian conquest. In explicit comparison and contrast to Chavchavadze's anthropomorphic, sublime Terek, Bavreli refashions the Mtkvari into a patriotic Georgian, who refuses to go abroad, who refuses, in effect, to travel at all:

However angry the Mtkvari may be, still I love it. While the Terek brings many into rapture with its noise and terrible rush, with its richly adorned banks and it awakened many feelings in people, but no, I don't love that; I came to hate the Terek without seeing it, for the Terek is not devoted to the fatherland, as is the Mtkvari. The Terek runs off from the fatherland into foreign countries and beautifies the lands of others, and not our own ... I love the Mtkvari because it is self-sacrificing and devoted to the fatherland. ${ }^{12}$

If the Terek is two-faced and treacherous (again recalling Chavchavadze's characterization), seeking to go to foreign lands, the Mtkvari is devoted and patriotic, a river that flows through and for Georgia alone. Just as Chavchavadze used the figure of the Terek River to make geopoetic arguments and invoke oppositions of imaginative geography, such as that between Europe and Asia, Georgia and the Caucasus, so Bavreli extends this language of rivers both to intertextually link his own travels here to those of a more famous aristocratic writer elsewhere 
and to extend this imaginative geography in space into Ottoman Georgia, producing a threefold opposition between the Mtkvari (the familiar European Georgia), the Choroxi (the alienated Ottoman Georgia), and the Terek (the Caucasus, or perhaps the cosmopolitan imperial space of a chinovnik in Russian service like the man seated next to him, including many Georgian chinovniks and even Russian-educated Georgians [the original meaning of tergdaleuli] like Chavchavadze himself besides) (see map 2 for the locations of these three rivers).

But the comparison has an unintended reading, too: the Mtkvari could be taken as a figure for "travel" in the Georgian sense, at least the Terek, and the Choroxi too, is a traveler in the normal sense, it seeks out foreign lands, but the Mtkvari never goes anywhere at all. The Mtkvari as "fellow traveler" is a figure for the predicament of the Georgian traveler, who travels but does not ever leave Georgia, a river whose circulation is like the circulation of Georgian travel writers, circulating within the imagined unity of Georgia. Bavreli and the Mtkvari are fellow travelers through much of their travels, though neither could be said to "travel" since they are never very far from home.

\section{Traveling Home: The Localist Georgian Traveler}

Like the Mtkvari River itself, Georgian travel writers seem to be loath to actually leave Georgia. No better illustration of this tendency can be found than the inaugural call for submissions for the popular journal Mogzauri ("Traveler") which reads in part:

The editors of Mogzauri asks lovers of Georgian historyarcheology, and geography-ethnography, to send to the editors articles of general interest about the history, archeology, geography and ethnography of Georgia. ${ }^{13}$

As one contemporary commentator noted, to illustrate his point that "the contemporary Georgian does not like to travel, he doesn't like looking around as does a European": "We could not get used to traveling. Just consider we even founded the journal Mogzauri, but not even it could make us love traveling." ${ }^{14}$ Georgians are defined in opposition to Europeans as the local to the cosmopolitan, those who stay at home versus those who travel. 
Georgian travel seems to be a contradiction in terms. The feuilletonist Sano tried his hand at writing a letter of his travel from Tbilisi to Baku. He begins by discussing his title:

\section{Feuilleton}

Notes of a Georgian Traveler

(From Tbilisi to Baku)

I made up this title on purpose for today's letter. Were I to have written only 'Notes of a Traveler', the readers would think that some real traveler had really aimed at some scientific or social idea and intended such a journey to investigate it, as European travelers are wont to do for us. ${ }^{15}$

Sano is not a real traveler, a European traveler, but a Georgian one, just as this is not a real travel letter but a feuilleton. As a feuilleton version of a traveler letter then, meandering digression is the order of the day, every ancillary topic is covered, everything pertaining to the journey except the journey itself. We do not hear so much about the landscape as about its absence: everything the writer might have wanted to see cannot be seen; the journey for some reason is always at night, so one can see little or nothing from the windows; the railway itself is so devised as to wind a tortuous path through remote and deserted places, avoiding each potentially interesting human settlement by a number of miles, so that even important cities like Ganja (unless you actually go out of your way to see it on purpose) only appear in the distance from the railway station "only as about ten dim candles and lamps and nothing more." ${ }^{16}$ The price of the ticket, too, almost double what it should be, is blamed on the no doubt sublime, but invisible, mountainous landscape which the route is at pains to avoid: "It is the fault of Mount Kazbek and Elbrus, that you pay 12 roubles to Baku instead of six, you arrive from Tbilisi into Baku, in such a way that you can't see even one mountain ridge." ${ }^{17}$

But as the title warns, this journey which is not a journey is made by a travel writer who is not a travel writer (but a feuilletonist) and, indeed, not a real European traveler, but a Georgian traveler. And here 
is the greatest oxymoron, as the reader, surely, will already know, the main thing about contemporary Georgian travelers is that there is no such thing:

So as to not raise a false hope in the reader, I just now added in, that the traveler is a Georgian man, and you will be aware, won't you, how our urbane fellow-countryman travels. I should have said in the title, that this Georgian traveler was "of our times", so that it would be even clearer, with whom the reader is dealing, but the title came out too ugly and long and for this reason in the manuscript itself I am informing you of this quality of the traveler. ${ }^{18}$

The Georgian traveler is neither the familiar figure of the serious, scientific European traveler nor the Georgian traveler of old, when apparently, long ago, Georgians used to be of a more curious and cosmopolitan nature, believing themselves to be part of humanity in general and therefore loving knowledge, and accordingly, Georgians used to travel to far-off places in the East: "In this old times, as I was saying, we see the Georgian man not only in Persia, but Afghanistan, India, China, and elsewhere. He goes there to pray or to make war or to trade, he remains one, three, ten years. He sees many new things, new relationships, different wonders of nature and then, armed with new knowledge and experience, returns to his homeland, and imparts his mental treasury to friends and strangers." ${ }^{19}$ Travel for the contemporary Georgian traveler is nothing quite so bold, and its aims are much more modest. "Travel" and "traveler" are used, Sano says, when someone puts on a coat and hat and sets out on the road, "from let's say, a small village to a large village or a city. The distance traveled will be from 30 to 60 versts [kilometers, more or less]." 20

The distance traveled by the contemporary Georgian "traveler" are modest, and so are his goals. Much of the time this travel is forced upon the unwilling traveler, who must travel to the office of some police superintendent in a larger village or city by some specific date on some bureaucratic or police matter, lest they have to make a much longer trip to Siberia. If the reasons for such travel are not understandable to the traveler, at least there is a reason the reader will understand. But what of voluntary travel? What is its point? 
But for the most part Georgian travel means meandering from one place to the next, pointlessly, for no reason. The only reason for travel is for Georgian man to show his in-laws his abilities, for example ... to annihilate their wine. It could be that he has in-laws or friends who live at a distance, but the Georgian man nevertheless will dare to travel, so he can ascertain in detail, what quality of wine they have. This is typically the main goal, that a Georgian man leaves off his own supra and goes to the supra of others to devour everything. ... Our fellow countryman returns from far travels and all his reminiscences are where he drank how many stakans [glasses] and q'anc'i [drinking horns] on Monday, who did he compete with in drinking wine on Tuesday ... ${ }^{21}$

The Georgian man does not travel to learn, to find out new things, to learn the good and bad aspects of himself or others; his desire for new knowledge "is apparently buried in some deep gorge somewhere." As a result, it is no wonder "why we do not have any descriptions of not only of other countries, but of our own homeland," and all the while foreigners from God knows where "practically kill themselves to see our lovely country . . . at the same time our Georgian man, however, often only knows his own village and those places which can be seen from this village and which his eye can reach." 22 Thus, to the Georgian, slumbering in his own backyard, all the "wondrous victories of human ingenuity" in this age of mechanical wonders, like the use of steam-powered transport for travel on dry land and sea, have no "spiritual importance" for the Georgian man, "neither the steam train, nor the steam ship nor the telegraph have brought hardly any utility into our spiritual life." The Georgian man makes no use of the inventions of the nineteenth century that annihilate space and time (Schivelbusch 1977, 33), because, frankly, he doesn't want to go anywhere and is not interested in understanding or seeing anything, not only in other countries, but practically in his own country either.

How do we reconcile this model of travel with what we tend to view as being the essence of travel? European travel writing is a genre generated at the margins of self and other, familiar and foreign. Therefore travel 
writing requires traversing an imaginative geography and recapitulating the oppositions that inform such an imaginative geography, along the way finding them manifested "on the ground" in representative figures that tend to confirm the basic otherness of the territory traversed in relation to one's home. In general:

Travelers, then, impose on the foreign a demand that it should in some way proclaim itself as different from the familiar. At the same time, they define their own task as one of grasping that difference. Travel writings regularly note the disadvantages of those travelers who, for whatever reason, are unresponsive to alterity. (Chard 1999, 3)

Georgian travel writings like that of Sano, at least, are willing to do that last bit, for travel is mostly an opportunity to lambaste oneself, or other Georgians and Russians, for their unresponsiveness to alterity. Thus, it is not as though Georgians were somehow unaware of this definition of what it meant to travel, or had some competing definition. As Georgian writers like Sano and Proneli make abundantly clear, Georgians know perfectly well what it is, it is just that they don't want to do it. The project of Georgian travelers, by and large, does not involve interest in exploring the foreign, the unfamiliar, or the different. The Georgian traveler, too, because of the unstable position of Georgia between enlightened Europe and exotic Asia, shows little desire to explore the indeterminate position of Georgia within this space, the exoticism of Asia has no allure for him (and in any case any Tbilisian could find "Asia" in the bazaars of his hometown, as our feuilletonist reminds us in the preceding chapter), and Europe remains more of a geographical expression of modernity as such than a concrete destination. These places largely stand for categories or positions in a space of progressive teleology, ways of classifying or criticizing the locality, of finding fault with "useless" intelligentsia in the locality; they are not places to actually visit. In a way, too, the local peregrinations of Georgian travel letters are just an extension of the existing genre of correspondence. Just as correspondence allows stationary readers of Droeba located in this or that corner of Georgia to become writers to Droeba, so travelers are simply correspondents who are now themselves in motion, like the newspapers they read and the letters of correspondence they send back. 
Both are equally circumscribed by locality.

Even in places like Ottoman Georgia, the Georgian traveler often seeks the familiar in the strange landscape. Here and there, Georgian travelers find the familiar preserved in the form of Christian ruins, customs, superstitions, even alleged practices of "secret Christianity" practiced among the ruins of old Christian churches. Alongside ethnographic notes on the Georgianness of the inhabitants, the most extensive descriptions are devoted to the ruins of old churches, usually attributed to the illustrious empire of Queen Tamar. But in general, Ottoman Georgia fascinates not because of its Oriental alterity, as it would European traveler, or even the picturesque assemblage of the ancient Georgian ruins and the exotic Ottoman present, but because of the ruins of Georgianness, both moral and material, that preserve a sense of familiarity in the landscape. Here, in the erstwhile center of Georgia's past glory, ruins of Georgia's past are common, perhaps more common than in Georgia itself: "in the district of Ardahan, wherever a person goes, they encounter old remains at every step: ruined churches and castles." ${ }^{23}$ Accordingly, the traveler to Ottoman Georgia travels in time, not in space, and the most typical kind of correspondence is ultimately the genre of "archaeological travel."

Georgian travelers define themselves not so much as travelers in space, as in time. This emerges most clearly if we compare the two most distant places that Georgians traveled to in the 1870s: Ottoman Georgia and Europe. Georgians who traveled to Ottoman Georgia were above all archaeological travelers, travelers seeking an image of a lost Georgian empire under Queen Tamar: their landmarks are the ruins of Georgian churches, which, more than anything else, attract attention and give license for their travels and were textualized as a kind of monumental palimpsest. At the same time, it might be said that travel to Europe was travel to the future; there, in Europe, one went to witness the destination of a progressive civilizational teleology, to see world exhibitions and find models for progressive reform of Georgia, and most of all, to read newspapers.

Traveling to the Past: The Archaeological Traveler

Bavreli, taking his leave after dinner with some local Tatar inhabitants in Ardahan, extracts from the locals a strange promise: 
We took our leave. My last request was that, whatever old relics [nashti] there were: fortresses, churches and halls, that they not destroy them. They gave me their promise. I left.

He then lectures the reader on the moral significance of these material ruins:

It will not be unseemly, for those who have possession of [these ruins] to pay attention and issue commands to others, that these remains [nashtebi] which have remained from the old life, that they will not ruin and destroy them even more. Maybe our future [generations] won't be as cold-hearted as we are; maybe these ruins, witnesses of our past life, will have influence on them and they will become sign posts showing them the way for another life. ... . ${ }^{4}$

Bavreli's peculiar request needs to be understood within a broader episteme arising in the 1870s, a period in which the "archaeological journey" becomes a special subgenre within the broader genre of travel letters, a subgenre especially associated with Ottoman Georgia. By the 1870s, Georgian Romantics had made ancient churches into secular objects that were already becoming hybrids of the Romantic discourse of ruins (eliciting a subjective lyric response) and a newer archaeological discourse that treats churches as historical national monuments (eliciting a historical, memorial response) (see Manning 2008). As monuments, these old Georgian churches stood in opposition to the new Russian ones as icons of differences in monumental time, in which the temporality of Georgian orthodoxy and Georgian empire encompasses that of Russian Orthodoxy and Russian Empire by an order of aeons. Vaxtang Orbeliani's (1812-1890) poem, "Two Buildings," from the same period (1881) contrasts a contemporary (Russian) freshly painted building to an old Georgian one from the period of Tamar, which is encrusted with weeds. The first building has weak walls which are easily destroyed, and even its ruins will quickly disappear into the earth: "it has no past, nor will it have a future." The second one, including a "holy church," while 
abandoned and overgrown with weeds, has no fear of the flow of time, "it stands heroically, built by the hands of heroes," and "if someday its walls are destroyed, its remnants (shtenni) will remain forever," "because a great past has a great future." If the Russian "imperial sublime" (Ram and Shatirishvili 2004) emphasizes the spatial vastness of empire, projected both on vertical and horizontal spatial axes, by which the Russian Empire both encompasses and surveys from a great height colonies like Georgia, the Georgian imperial sublime instead is projected onto the canvas of time, encompassing the Russian Empire on a temporal order of aeons.

In late Romantic poems, we already see signs that old churches are moving from the aesthetic order of ruins to the epistemic order of monuments, from the subjective lyricism of Romantic poetry to the dispassionate disciplinary empiricism of Georgian archaeology, from the period of "romanticism" to the period of "realism" (Lotman 1984, 142). Romantic ruins are mysterious, illegible, hieroglyphic; archaeological positivism would replace this mystery with historical knowledge as surely as it would remove the moss from the facade to read the inscriptions beneath (Edwards 1999, 16). The new archaeological understanding assimilated old churches to the category of monuments (dzegli), which included verbal texts (including both written monuments like Rustaveli's poem Vepxistqaosani as well as oral texts passed from mouth to mouth) as well as other secular buildings like fortresses, all of which were felt to be traces (k'vali), remnants (nashti), signs (nishani) of a once great Georgian civilization, to be monuments and witnesses of the culture of a Georgian nation. ${ }^{25}$ Each kind of monument (architectural, textual, customary, oral) would become the object of a corresponding emergent academic discipline (archaeology, philology, ethnography, and folklore), both within imperial academies as well at the amateur level in the Georgian popular press. Each emerging discipline (archaeology, ethnography, folklore, philology) constituted itself with respect to a specific sort of empirical object but were understood to be homologous in methodology and aim (compare van der Veer 2001, chapter 5). The work of archaeology in piecing together the scattered ruins of the nation (associated with rulers like Tamar, to whom in the popular tradition in Russian and Ottoman Georgia these monuments were usually ascribed) were likened to the philological work of reconstructing from various existing manuscripts a singular, authoritative Ur-text of the national 
epic poem (associated with a contemporary of Queen Tamar, the poet Shota Rustaveli). All these new disciplines were also united in having a single transcendent object; they were all disciplines of "the nation," each revealed a specific kind of national specificity. Accordingly, each disciplinary object, each "monument," could be assigned, once and for all, on the basis of original authorship, to exactly one such transcendent historical national unity.

These changes in the epistemic order occurred around the same time as the Russian conquest of territories of Ottoman Georgia in 1877-8. These territories had formed the center of Tamar's empire in the twelfth century, but had been under Ottoman rule for over two centuries. As we have seen, Ottoman Georgia had become the site of a major current of irredentist fantasy of the cultural and political reunification of these "long separated brothers," Ottoman and Russian Georgia. In the period leading up to the war, and in the immediate aftermath, Russian imperial spies and archaeologists (all of them Georgians) and Georgian newspaper correspondents, respectively, scoured the countryside of Ottoman Georgia, finding little that was Georgian there other than ruins of churches. Even if the people often no longer resembled Georgians in language and especially religion, the ruined churches that dotted the landscape were signs that the land itself, if not the people, belonged to Georgians.

With the "archaeologization" of churches, the interpretive custody of old churches passed by slow degrees from Orthodoxy to the nation, from religious sites of worship of God to secular monuments of the nation. Georgian travelers in Ottoman Georgia like Qazbegi and Bavreli continually drew attention to the nature and quality of ruins, particularly of churches, always searching for telltale inscriptions that would permit identifying them as "Georgian," but rarely tarrying as their forebears might have done to emit a lyric groan or melancholy sigh. Since local Georgians were usually Muslims (hence Bavreli calls them "Tatars" above), these churches had ceased to be Georgian religious objects and were now freely appropriable as secular objects belonging to the Georgian nation. Georgian travelers like Bavreli worried that the local Muslim population would destroy these ruins to use the old stones for building purposes and requested that they not do so. But as the Ottoman Georgian Tatars fled these conquered lands, Georgian writers worried that the emptied-out landscape was filling up with Armenians, 
and they were even more scandalized that some such churches were being appropriated by the local Christian populace as Armenian apostolic churches, often accusing the local Armenian population of intentionally hiding or defacing Georgian inscriptions (e.g., Bakradze 1987 [1878], 41). ${ }^{26}$ Accordingly, every church was scoured for signs of Georgian inscriptions that would establish once and for all that a given church was part of the Georgian, and not Armenian, religious, and therefore national, patrimony.

In this discourse, the appropriation of ruins of churches was strongly textualized, ruins were seldom illustrated as parts of sublime landscapes but were more often transcribed as textual objects. Bakradze's Archaeological Journey to Guria and Ajaria (published in Russian in 1878, describing a journey to Ottoman Georgia that took place in 1873), shows a strongly textualizing approach to monuments. The only illustrations of churches in his book are a paltry few drawn by Giorgi Qazbegi (18391921) during an earlier espionage mission in Ottoman lands (published in 1875), while his own illustrations, numbering over a hundred, are all transcriptions or illustrations of inscriptions found on these churches. This "textualizing" shift is registered even in late Romantic poetry from the period. Vaxtang Orbeliani's poem "There Is a Place" (Aris Adgili ... ; Orbeliani 1879) about Gelati Monastery, the burial place of Tamar, begins with a description that otherwise shows all the typical affect-laden qualities of the Romantic ruin, the sublime and deserted surrounding landscape, the moonlight, and especially "the moss of a thousand years" that decorates it. However, the ruin is first of all a monumental text: "Its walls ... are a notebook" (amis k'edeli ... aris rveuli), that tell the tales of thousands of years, of its glorious builders, specifically, of Tamar.

Just as the architectural landscape is read as monumental text, textual monuments are read into the landscape. Travelers to Ottoman Georgia make the strange Ottoman Georgian landscape familiar by seeing in it illustrations of passages from the epic poem by Rustaveli. As we saw above, one traveler thinks to see in the Ottoman Georgian city of Batumi a fabled city from Rustaveli's poem; ${ }^{27}$ while Bavreli, daydreaming on a boat floating down the Choroxi River in Ottoman Georgia, thinks himself to be "in the land described by Rustaveli." 28 The two kinds of monuments, ruins, and texts move from metaphoric to metonymic parallelism: Ottoman Georgian churches are themselves searched for signs of texts, inscriptions, and old books in Georgian. At the same time, parts 
of the Ottoman Georgian landscape are searched for scenic spots that Rustaveli had in mind when writing his epic poem. The ruins authored by Queen Tamar and the epic poem authored by Rustaveli become two series of monuments, architectural and literary, that, taken in tandem, allow the imagining of Georgia, an ancient Georgia whose center was Ottoman Georgia.

To further reinforce this metonymic alignment of the archaeological and philological orders of monuments, the first deluxe illustrated print edition of Rustaveli's epic poem (1888) made this connection explicit by having the decorative borders and capitals of this textual monument be drawn from the decorative reliefs found in old churches. As the introduction to the edition itself notes, "Almost every monastery and fortress,-Mcxeta, Uplis-cixe, Betania, Kutaisi, Gelati, Sapara, Kabeni, Axtali, Pitareti, Samtavisi, Ateni-has its part [c'ili], has imprinted its mark [k'vali], in this book" (Kartvelishvili 1888, 325). On this simple, decorative level, this text stands as a kind of print microcosm of the national macrocosm. Here the monumental text contains within it parts ( $\left.c^{\prime} i l i\right)$ and marks or traces (k'vali) of the order of architectural monuments which mark the historical territory of Georgia, thus linking together the order of circulatory textual monuments (the first print edition of the poem) with the immovable order of archeological monuments as an intertextual series.

The assimilation of churches to the quasi-textual order of the "monument" was also a decisive move to transform them into objects of a secular intelligentsia discourse. On the eve of conquest, the intelligentsia project for Ottoman Georgia was an explicitly secular one, which emphasized only putative commonalities (a common culture and language) between Russian Georgians and Ottoman Georgians, ignoring or downplaying the religious divide between them as Christians and Muslims. This approach was in explicit opposition to state-sponsored programs of proselytism as represented by the Society for the Restoration of Orthodoxy (see above)..$^{29}$ The assimilation of churches to the authorship of the monarch Tamar alongside the secular epic poem by her contemporary Rustaveli represented, in effect, a claim by the secular Georgian intelligentsia for authority over these monuments and their interpretation. As time goes on, such intelligentsia discourses about churches as monuments of culture become ever more explicitly critical of the Russian Orthodox Church. 
Lastly, the fact that these old churches were ruined temples in distant lands deserted by Georgians made visits to them into pilgrimages as well as expeditions. Starting with the travelers of the 1870s, "archaeological excursions" and "archaeological descriptions" have become a distinct genre within the broader category of travel letters, and by the 1890s, churches had become exemplary subjects for the nascent social practice of amateur photography. While "archaeological excursions" have a solid non-Romantic epistemic alibi, the fact that the ruins surveyed were always Georgian ones showed that the aesthetic discourse of the Georgian imperial sublime was always a factor. One Georgian travel writer and amateur photographer (Alxanishvili, whom we met above), summarizing his own motives for traveling to Ottoman Georgia, pointed to precisely this sense of the sublime one could only feel there, in Ottoman Georgia, the erstwhile center of a large Georgian empire:

The reason for our travel was to inspect and photograph, along with inscriptions, old remains [nashtebi], signs [nishnebi] of a strong and lively life of Georgia that once existed here. Lo, he who wishes to feel the strength of the Georgians in the past must travel to these places. ${ }^{30}$

What a Georgian intelligent might experience in these places of secular pilgrimage is a kind of Georgian "imperial sublime," a melancholy sublime mingled with the picturesque, in which one surveys the strength and life of a quondam Georgian empire fallen into ruin and decay. In Artvin, Bavreli has met up with some young Georgians who have bought wine and they go into the ruins of Artvin's ruined fortress, which stands on the cliffs overlooking the Choroxi, to drink it. Here they find the ruins of a complex technology of wine storage (a series of interlinked wine jars [kvevri]), which attests that "once Georgians lived here." Appropriately, here they spread their tablecloth [supra] and drink their wine. One of his "chirruping" companions offered the following toast in the register of this "imperial sublime":

Brothers, let us drink to the memory of those brave heroes, of our ancestors, who once apparently lived here and battled for the freedom of their families before violent and barbaric enemies! May God will that their 
good feeling be passed on to us! May God will it! Cheers, Cheers!

He offers that the "chirrup" of his companions will not be pleasant for every ear, "but fortunately, no one was listening other than the sheer cliffs, and only they joined in our song." ${ }^{11}$ Toasting the ancestors among the ruins, with only sheer cliffs to listen and answer, produces the sublime and melancholy sense of loneliness and loss of past glories that characterizes the Georgian "imperial sublime." (I owe the idea of a specifically Georgian "imperial sublime" to Zaza Shatirishvili.)

Perhaps the most striking difference between travel letters about Ottoman Georgia in the 1870s and the explosion of ethnographic writings about the mountains of Georgia in the 1880s is the way that the material aspects of the landscape, in particular ruins, dominate over the moral characteristics of the contemporary inhabitants in the former, and not the latter. It might be added that the material ruin stood as a handy figure for the moral condition of Georgianness among the Ottoman Georgians, whose Georgianness was much like a ruined building, able to be deciphered in shards and fragments of language and custom and perhaps even practices of "secret Christianity," but nowhere found in its original, integral form. One commentator from Ottoman Georgia in 1882, complaining about the general disinterest of Georgians in "their brothers" and distorted picture presented in the press about the moral condition of the people, treating them just as if they were like any other tribe of Georgians, advised that, in reality, only in their external appearance and among the monuments of language, specifically oral texts, could the Georgianness of the people be clearly descried, "-all the rest, which constitutes the specific characteristics of Georgians and by which they are differentiated from other neighboring peoples has been smashed to smithereens . .."32 But if the order of material ruins stood as a metaphor for the moral ruins of Georgianness of the Georgians living on these ruins, there was also, as Bavreli suggests above, an indexical, metonymic effect: perhaps these material ruins, associated in the popular memory with the figure of Queen Tamar, could act as a form of the Georgian "imperial sublime," act to instill memory of Georgianness, of a lost Georgian empire associated with the name of Queen Tamar, among the people. Alongside this secular "imperial sublime," in which Georgians experience their past glories by pilgrimage to the ruins 
of Ottoman Georgia, Georgian intellectuals imputed other ennobling moral effects of material ruins on the Ottomans themselves.

Alongside the way that these ruins served as a secular reminder for the Ottomans of their Georgianness, their prior belonging in a large Georgian empire, there was also frequently imputed to the Ottoman Georgians practices (based, it appears, on local Muslim folklore or rumor) of "secret Christianity" revolving around these abandoned ruins in the woods. ${ }^{33}$ For the most part, the local accounts place these practices in the past, part of a narrative of conversion, while the Georgian accounts move them into the present tense. For example, Bavreli quotes one Georgian Muslim interlocutor as reporting of his own people that they used to practice secret Christianity:

We used to be Georgians [Kartvelebi, presumably in the sense of 'Christians'], I learned this from my grandmother. That dearly-departed one knew Georgian, and read and wrote it like water. God, who seeks out his qulebs (monebs ['servants']), undoubtedly looking down upon them from above, our grandparents saw, that Islam was the true faith and accepted it, but among them many Georgians [Kartvelebi] remained, and secretly retained their old faith.- They say that by night they would go into the woods and there they would pray in the church. They say that the remains [nashti] of that church are even now in the woods. Our people learned this and caught them all at once. ${ }^{34}$

In a sense, imputing to Georgian Muslims practices of "secret Christianity" points to a similar "return of the repressed" in their own secular interpretation of monuments: by these means the Georgian intelligentsia can construct the population and the ruins simultaneously as belonging overtly to a secular Georgian order (nationality without religion), and simultaneously give both the monuments and the people a covert religious (Christian) dimension which again links religion to nationality.

The moral effects of Christian monuments on other set of Muslim Georgians (the Ingilos, living in contemporary Azerbaijan) is also the theme of a set of fictional travel notes written by Droeba correspondent Mose 'Ingilo' Janashvili. These fictional travel notes present themselves 
as a survey of the Georgian ruins of this erstwhile part of Georgia (Saingilo) by a group of fictional Georgian travelers (fictional because, as Janashvili points out, other than himself, no other Georgian has ever traveled there). Like many real Georgian travelers in Ottoman Georgia on which he is modeled, one of these travelers narrates the sort of "imperial sublime" that the ruins would provoke in any Georgian (if, presumably, any Georgians ever decided to actually go there): ${ }^{35}$

'Lo, those remains [nashti],' [one of the travelers said] said, pointing to the ancient ruins of a temple, 'surely can awaken in the heart of a Georgian man warm love towards the glorious ancestors and at the same time venom towards their many enemies ... ' 'Here,' he continued, 'at one time was a great city, named Qumi. We are convinced of this not only by the traditions passed done word of mouth by the tongues of the people, but also by our [historical chronicle] "The Life of Kartli" ... In the laps of these lovely mountains apparently once life bloomed. ${ }^{36}$

While the primary purpose of this set of travel letters is to describe the ruins of this sublime landscape from the imaginary perspective of a group of Georgian travelers, Ingilo also has his narrator comment on the parallel moral effects of these same material ruins on the "Lekified" (Lek is the general east Georgian ethnonym for a wide range of Daghestanian Muslim mountain groups) people of the village of Belokani:

One thing makes us happy, this traveler went on, that all these Lekified people have a great love towards our ancestors. This love has apparently remained in them with the help of all these manifold beautiful remnants [nashtebi], which here before our eyes smile at us now. All the local villages and forests are full of such remnants. For example, Belokanians have before their eyes diverse churches, the traces [k'vali] of the ruined dwellings of Georgians and so on. You cannot imagine with what delight and love they recall our queen Tamar, a woman whose like never yet been born nor will be. ${ }^{37}$ 
The abandoned churches in the woods, the churches, along with other material signs of Georgianness like fruit trees and grapevines gone wild, ${ }^{38}$ serve not only as historical evidence of the Georgianness of the people for the archaeological traveler, but also, more importantly, a reminder for the people themselves.

\section{Travels to Europe: The Occidentalist Georgian Traveler}

Unlike a Russian traveler, who, though uncertain of their Europeanness among Europeans, still can confidently project themselves as a European traveler in Asia, Georgians cannot safely assume a European point of departure as the "familiar" to contrast with the obvious "foreignness" of the East. As Sano implied, European travelers are "real travelers," and Georgians are not travelers nor, it seems, Europeans. An Orientalist Georgian traveler like G. Qazbegi is certain of the validity of a basic cosmological divide between Europe and Asia and can assign everything exhaustively a place within this imaginative geography, except himself. Indeed, throughout his description of Ottoman Georgia, the implied interlocutor is a European science which knows nothing about and has never seen these lands (and still has not, since Qazbegi does not identify himself as a European) (e.g., Qazbegi 1995[1875], 29, 70, 100, 134). ${ }^{39}$ Perhaps this insecurity of position within the master dichotomy that organizes most nineteenth-century imaginative geographies (Orientalism) leads Georgian travel writers and travelers to beg the question, or even avoid the question, of where they stand in it. Georgian travel writing of this period (before the Russian revolution), when it travels abroad (which is rarely), does not head east or south (since for the Russian empire, Asia is as much south as it is east). It heads north (to the imperial metropole) and west (to Paris), and then rarely.

European travelers, safe in their knowledge of self, can afford to revel in the alterity of the Oriental other. Travel in the Orient defines the European as European, but the historical mission of the Georgian intelligentsia is predicated on a nonidentity between Georgians and Europeans. After all, the defining mission of the Georgian intelligentsia was to mediate between Georgia and Europe, to bring Georgia into Europe:

Among us the mission of the Georgian intelligentsia 
after the end of serfdom was-the development of the diverse national life into European forms. ${ }^{40}$

The intelligentsia mission is an almost platonic demiurgic one of transformation, to mediate between the unchanging (because perfected) forms of European life and the obdurate and diverse materials of Georgian national life. This is still the master narrative of the Georgian intelligentsia, as it has been, virtually without a break, for over a century. Because the historical role of the intelligentsia is to bring Georgia into Europe, the first step of this "intelligentsia mission" is to go to Europe.

The problem is, of course, that Georgians really don't like to travel, even to Europe. This is something which Sergi Mesxi (editor of Droeba) finds even in his own character: at the beginning of his journey to Europe, remonstrating in part with himself, Mesxi chides all would be intelligentsia reformers who wish to make pronouncements on progressive and enlightening reforms in their own society, who have not seen with their own eyes the model upon which all such reforms must be based, Europe, but rather make their unpersuasive pronouncements based on "knowing two cities in Russia and Tbilisi and Kutaisi," and from their apartment in Sololaki [a neighborhood in Tbilisi] "preach to Georgians that they should stop sleeping, put their hands to new tasks and a new life and adopt the life of Europe, that life, which you yourself have not seen and not gotten to know?"

For Mesxi, the very alterity of Europe (opposed now to Russia and Georgia both) recommends itself as a source of models for liberal reform. Unlike traveling in Asia, journeying to Europe one experiences an alterity which is also universality, a set of models to be adopted by all. The life of Europe is the best representative of life in general, and the life of France is the best representative of life in Europe:

I wanted to see that Europe, whose life, that a man might really assess it, composes the life of the whole world. And that France, which, for its part, is the best representative of the life of Europe. I wanted a little, even in passing, to become acquainted with and catch sight of the life of those peoples, whom many envy, whose various arrangements and rules others imitate. Where would I see 
all these things if not in Western Europe, and in its best corner, France! ${ }^{41}$

European forms of life stand to Georgian customs as the future to the past, whereas the role of the intelligentsia is to describe and critically assess Georgian customs, relicts of past life, as to whether they are "harmful and impoverishing" (and therefore to be eliminated) or not, the intelligentsia role with respect to Europe is to understand these European forms with a view to their eventual adoption in Georgia.

If Paris will be the prototypical incarnation of the pinnacle of Europeanness, "the best representative of Europe," his first stop along the journey is the World Exhibition in Vienna, where he will find his own progressive Eurocentric cosmology incarnated in a microcosmic display, from which the whole imaginative geography in which Mesxi is traveling concretely is quasi-ritually displayed to be taken in, if not at a glance, at least in the course of a couple of days. Such a "world picture" represented a condensed, almost fairy-tale microcosm version of the imaginary journey that Mesxi was undertaking:

Universal expositions represented this 'single expanded world' in a microcosm, celebrating the products of industry and technological progress and displaying the entire human experience. Other cultures were brought piecemeal to European and American cities and exhibited as artifacts in pavilions that were themselves summaries of cultures... World's fairs were idealized platforms where cultures could be encapsulated visually-through artifacts and arts. ... (Celik 1992, 1)

Mesxi is very familiar with the conventions and expectations of such a spectacle, he is almost a connoisseur. (He has virtually memorized the arrangement of the earlier French (therefore better) exhibition, for example, from a newspaper account). Accordingly, Mesxi is disappointed with the Vienna world exhibition:

Every exhibition must be organized so that the viewing and recognition of the displayed objects is possible and made easy not only for knowledgeable persons and 
experts, but for everyone. Everyone should be able to see easily, which art has risen to a higher level in which country and which people are more practiced in which art. This is the first and foremost condition of every exhibition and if this cannot be fulfilled, such an exhibition, you must know, cannot bring any benefit to human arts. $^{42}$

Mesxi, a confirmed Francophile, compares it unfavorably with the French exhibition of 1867 (which, again, Mesxi himself did not actually see). Unlike the Vienna exhibition, in which the different peoples of the earth had separate exhibitions laid out iconically in terms of their relative disposition on the globe, in the French exhibition, the circular building was laid out into galleries with two intersecting principles of organization, one that gathered together all the arts of a single people, the other which was by individual sphere of art or science, and the individual peoples were laid out as a progressive narrative within that sphere, allowing comparison of the relative achievements of different peoples in the same branch of arts. Compared with the ideal exhibition found in Paris, the Vienna Exhibition is a disaster: this European representation lacks Europeanness (it is disorderly and chaotic, very unlike the straight and clean streets that he remarks upon everywhere as being impressive characteristics of European cities), and therefore, it also fails as a representation of the world, because you can't find anything specific anywhere, and as a representation of progress, it fails, because the incoherent representation fails to represent the ordering of the whole:

The Vienna Exhibition, however, is arranged almost completely unsystematically, incoherently: The Exhibition occupies a very large space, but in this space often similar things that belong together are displayed in completely different houses. One part of the machines, or industrial objects is in one building, the other part is somewhere else entirely; some of the crafts of one people are displayed in one place, some somewhere else entirely. So a man's brain becomes confused, the catalog cannot help you at all, you go around all day, look around and 
you can't arrange anything into or see any kind of order. ${ }^{43}$

Mesxi is not only interested in seeing a general map of human progress, he wants to know where Georgia and the Caucasus are located on that map. But because the map is so confusingly laid out, it takes him two days of searching before he finds it, and upon finding it, he is dismayed, mostly because it is nothing new. It turns out to be the very same exhibit that was displayed at the Moscow Polytechnic the year before, and he has nothing to add to what the Droeba correspondent said about that exhibit a year before (what that was, he does not say), adding that he will say only two words about the exhibit, and will say that later! He leaves Vienna disappointed.

In letter 7, Mesxi finally lays eyes on the city of his dreams, Paris. From the outset, Paris itself presents itself as a "fairy-tale" spectacle like a world exhibition, a sublime vision with its corresponding subjective states of astonishment and pensiveness, except here it is a sublime spectacle of infinitude, a city that cannot be taken in by the eye, streets that are infinite, houses that are like towers.

The first time a man lays eyes on Paris, the first time he step on its ground, has a stupefying and pensive effect on the mind of a man. His eye sees a city too vast for the eye to encompass, like the city of a fairy-tale, the endless straight streets, the six and seven storey houses raised like towers and rising above these houses the even higher churches, towers and monuments. . . . You feel that every foot of this city's earth is watered with blood shed for the freedom of France. You feel that you are on that ground, in that city, which is at one and the same time the head and heart of all France, where political and social life pulses.... ${ }^{44}$

Meshki's stupefaction at encountering his own Occidentalist fantasized fairy-tale city, the sacred center of Europe, is such that he can only compare his own Westernizer's fantasy come true with its corresponding antipode within this Orientalist imaginary, a Muslim (whom he characterizes as "worshippers of Mohammed") who first completes the hajj to their holy city. While presenting his journey as an Occidental- 
ist inversion of an Oriental's hajj to Mecca, Mesxi does not become a Westerner, but insists on his nonidentity, presenting himself as "A man from the East":

I do not know, what would happen to and with what feelings the worshippers of Mohammed enter their holy city - Kaba [sic]; but I think, that their feelings must be very similar to the feelings of a man who has first arrived from the East in Paris! ${ }^{45}$

Paris is a fairy tale come to life, but Mesxi wants to correct the existing Georgian fairy tale about Paris, that it is a city whose "contemporary" life is typified by its public, social life ("theatres, a myriad ballets, evenings, concerts ..."), in much the same way that he argues elsewhere, Georgian pseudo-intellectuals reduce European progress and enlightenment to a matter of Parisian hats and dresses. He summarizes as follows:

We all, who are raised on our own kind of books, have created an obstinate idea, about "contemporary" Paris and its life. There [mand, i.e., where his readers are, Georgia] from every side we hear "Paris is such a city, such a crazed life exists there, so many entertaining, diverting, and attractive things are found there, that not only is study impossible there, but a restful life and generally thoughtful work too." ${ }^{6}$

"This is a mistaken and false idea from beginning to end," Mesxi tells us; there are plenty of things to do in Paris, like any city, he adds, but also here as elsewhere there are many serious people who want to work or study, especially since all forms of entertainment turn out to be quite expensive, while living the life of the mind in Paris turns out to be very cheap. But for Mesxi, the life of Paris that attracts him is not the social life of popular entertainments, for he is an intelligent; for him the only life is the political life, the Paris he wants is the revolutionary Paris. For Mesxi, the editor of Droeba, the political life of a country to be assessed by looking at its newspapers, and here Mesxi is certain that "Paris" (and not Germany) is the answer to the question, "Which has the first place in the description of the political life of the people?"47 
Leaving Paris behind, a city which is, even now, the motherland of freedom and the newspaper for Mesxi, he is saddened, comparing himself to a bride oppressed by her mother-in-law, who has had a brief respite of relative freedom as a guest, and now has been recalled back into servitude. He recalls that he began his journey with the consolation that in travel, at least, he can leave behind all those "persons, affairs, and interests which always fill my heart, which always remind me of my shortcomings and 'our' difficult circumstances." In short, in particular, it becomes clear that the main benefit of leaving Tbilisi is to escape other Tbilisians, "at least I will rest and I will no longer see various people and events such as have a deadening effect on me," he thinks. ${ }^{48}$

But alas, other Tbilisians can travel too, and he dedicates his eighth and final letter (like Chavchavadze's travel letters, Mesxi's journey is divided into eight stages) to discussing the problem of going to Europe and finding other Tbilisians there. In Poti, as he is taking his seat on the boat that will take him across the Black Sea to Europe, he runs into an acquaintance from Tbilisi (whom he will later call Polkovnik), who, after exchanging greetings, takes a seat next to him and begins to ask Mesxi about his itinerary. The deadening prospect of having a boorish fellow countryman as his constant companion raises its ugly head:

—Where are you headed?

-To Vienna.

-To the exhibition?

-To the exhibition.

-Very good, I am going there too. From there do you intend to go somewhere?

-To Paris.

-Even better: I'm also going to Paris. Then we are fellow travelers. It's very nice to have a fellow traveler on the road! ${ }^{49}$

Mesxi realizes he is in for a long voyage as his new travel companion "twitters away a whole hour with incessant chatter," so he takes out a book and slowly begins leafing through it, and somehow signals with a glance to his chattersome travel companion that he is no longer paying attention to his chatter and wishes to be left alone. His companion somehow gets the message, stands up, and seats himself with some other 
acquaintances, and other than brief greetings, they remain separate for the remainder of the voyage. In Odessa, Mesxi sneaks off the boat, hoping never to run into this friend again. The plan is a success, he makes it alone to Vienna, and thence to Paris. In Paris, however, his luck runs out: one evening while he is out walking and window-shopping with a French student along the Boulevard des Italiens, he hears a familiar voice greet him in Russian. There is no help for it, he must obey his fate; he exchanges cards with his traveling companion from Poti, Polkovnik, and they meet up once or twice for meals.

This Polkovnik appears to be a dreadful boor. In restaurants, he takes it amiss whenever the garcon serves anyone else seated in the restaurant, "some simple merchant or who knows, even a clerk!" ahead of him, stewing in anger through the meal, "only from time to time looking over at the garcon wrathfully, as if to he wished to instill fear and trembling in his heart with his blazing glare." ${ }^{50}$ After an imagined slight having to do with the dessert tray, Polkovnik rages, "What can a man do? Here is their égalité! Wherever you step, everyone has written on their face liberté, égalite, fraternité! Here is their liberty, unity [sic] and brotherhood, that they don't know how to pay respects to their betters and they lack manners!"51

In short, Polkovnik understands very well how service in a French restaurant enacts in everyday life the revolutionary principles of liberté, égalité, fraternité, it's just that he is allergic to these things. He requires a more aristocratic standard of service. After reporting another horror story of égalité at another restaurant, where the two servers have the temerity, after they are done serving the guests, to sit themselves down at their side the very same host's table and begin eating, Polkovnik describes his attempts to instruct them in manners by yelling "Garcon!" every time they sit down, but his attempts to instruct French waiters in the fundamentally aristocratic etymology of service are in vain, and he decides he must leave this intolerable country. ${ }^{52}$ And true to his word, he does leave Paris, spending three days in London, upon returning counsels Mesxi to return home to our "blessed land." Thus, after spending three days in Vienna, a week in Paris, and three days in London, "now, when he returns home, without a doubt, he will say 'I traveled Europe. The people of France are in decline, Germany is 10 times more advanced in every respect, England is a wealthy country,' etc. etc." 53 


\section{Ardanuji by Moonlight: The Orientalist Georgian Traveler}

If intelligentsia like Mesxi travel to Europe to see the future Western world they dream for Georgia, to travel to Ottoman Georgia is, in terms of imaginative geography, to travel in the opposite direction, or rather two opposed directions: to the exotic East (despite the fact that they are literally moving to the southwest); but also, as we have seen above, into the Georgian past. The land of Ottoman Georgia has once been, and is now again, Georgian, and yet, like the babble of the Choroxi, it and its people have become strange, Oriental, and even the familiar Mtkvari changes its tone in Ottoman lands: "If no one were to tell you that this is the Mktkvari, you wouldn't know you were looking at the Mtkvari. That noisiness, that haughtiness, that strength, here changes into peacefulness." Accordingly, Bavreli's descriptions seem torn between localism, his desire to see a familiar fragment of Georgia in the contemporary land and its people, and not merely content himself with the Georgian ruins that dot the land, and a desire to give himself over to the exoticizing Orientalism of a European traveler. Sometimes, in the wooden houses and green fields of an Ottoman village, he thinks to see a fragment of Imereti: "the villages around here, their buildings and the nature, too, is almost Imereti. ${ }^{54}$ At other times, he poetically adorns the features of nature with Asiatic dress: "the darkness of night hid the local area under its curtain, as a chador unfairly hides a beautiful Tatar woman." 55 "The sun crossed over towards the mountains. In the light of the sun's rays the blue peaks of the mountains were painted pleasingly with a chador of snow." 56

In this strange yet familiar landscape, Bavreli frequently divides the landscape into elements of two discrete temporal series, the Georgian past, figured usually as a ruined church, and the Ottoman present, which is figured variously in the landscape, the contemporary buildings, or the people. This produces a picturesque contrast, in which Christian ruins and Oriental gardens are equally important scenic elements which compose a picturesque assemblage:

From afar Grtvani appears as a beautiful city, decorated with gardens. Olive groves further beautify the city. . . . It was in the evening at the time of prayer. A Tatar in a white chalma had gone up onto a great cliff and was 
offering a prayer to Allah ... The houses of the village [of Lomasheni] are almost entirely hidden from view by the olive gardens. It has a pretty location. One side looks out over the Choroxi river, on the other side are high cliffs. Above Lomasheni (one verst away) there stands an old church. ${ }^{57}$

The two are ordered as a temporal opposition within the picturesque whole, as the order of ruins belongs to the melancholy lost world of Christian Georgia, while the gardens and olive groves, the praying Muslim to the Ottoman present.

At the same time, Bavreli is at times a strictly picturesque traveler, seeking after spots whose contrasts are important not because they illustrate the contrasts of an Orientalist imaginative geography but only because they give rise to picturesque aesthetics. The neighborhood of Artvin seems to abound in such picturesque spots:

Up to this point you have seen the Choroxi from afar, here, now we come close. Hither and there are little islands, narrow places, where red sand, collosal boulders appear. At one point the Choroxi has so narrowed the road by the cliff, that if a traveler doesn't dismount, he cannot pass.... Another picturesque [samxatvro] spot is the end of Artvin's bridge-on one side high mountains, olive gardens below, on the other side an old fortress on sheer cliffs. In the narrows between two cliffs sits a place like a little hamlet, with pretty shops. Above a rainbow-shaped bridge over the Choroxi. The Choroxi by the bridge is slow and deep. Below the bridge stand a thousand different kinds of qaighi (navebi ['boats']) and some of the Ajarians are hauling cattle in the boats quickly, some are unloading cattle from the boats. ${ }^{58}$

Elsewhere, albeit rarely, Bavreli moves decisively from the flattened affect and deadened nature of realism to a more Romantic Orientalist description that invests the landscape with expressive and fantastic elements. If in his descriptions of Lomasheni and Artvin Bavreli gives reign to his feeling for the Orientalist picturesque, at Ardanuji he gives 
full flight to his fancy, making the city into a locus of the Orientalist fantastic:

We came into Ardanuji. The remains of an old church on a high cliff, an equally old wall of mortared stone, which surrounds this small city, encircled by high harsh cliffs and bald mountains, gives Ardanuji a sort of fantastic appearance. $^{59}$

Finally, we meet up with Bavreli in the town where we first found him, dreaming up the news in the town of Ardanuji, a town which in a slightly earlier letter represented for him an empty desolate exile, almost an afterlife, from the circulatory universe of Tbilisi. Before, Ardanuji was situated in an Orient whose primary features distinguishing it from European Tbilisi was the absolute stasis and absence of circulation and life. Now Ardanuji instead comes to represent an positively valued fantastic land in which Bavreli can freely invest the landscape and people with all those expressive elements that he would not be able to if he were in Imereti in "European" Georgia, whose life and problems require a more prosaic realism. Ardanuji is, after all, part of a strange dreamlike land from the fantastic medieval stories of Rustaveli. ${ }^{60}$ It is in a "New Land (Seen in Dreams and Awake)" (the title, after all, of his long feuilleton taking place in Ardanuji); a land caught between empiricism and imagination, waking life and dreams. It is in the Orient.

"This little city," Ardanuji, standing a day and a half west of Ardahan, "used to be ours, and even now it has become ours once again. If it is ours, we should know what kind of city it is. Here I will describe it for you." ${ }^{61}$ His description dwells lovingly on the pretty streets, the wood and stone houses so close together that "you would think they are all descended from one mother and thus they have a great love for one another," and then moves on to the ruins, the cliffs, the surrounding nature. ${ }^{62}$ Having set off this "pretty little city" in description, after a brief prologue in which he extols the beauty of autumnal moonlit nights in Georgia, he invites the reader to imagine the equal or greater beauty of such a night in Ardanuji, he moves from simple description to rapture:

Who has not seen somewhere in Georgia beautiful moonlit Autumnal nights and has not been given over 
then to daydreams? . . Ardanuji has one of the most beautiful of these beautiful nights. Jupiter has not given to me a place in his Parnassus, I am not gifted by the heavens above with a fountain of rhythms pleasing to the ear, that I might have sung with verse my love for nights around here, which leads a slave of a weak nature like me into amazement. ${ }^{63}$

Bavreli ends his description of the landscape of Ardanuji with a portrait of the city by moonlight, as the city has moved from culture to nature, the noisy din of humanity changed to a still image of a landscape without the bustle of humanity.

Behold it has become dark. Twilight has spread its shadowy sheet. All of the inhabitants of this small city have sought out their own homes. Silence! That noisiness, that great bustle, the rumble of carriages, the ringing laughter in the circle of women - conversation, the seductive whispers of delicate educated women - is not present here! Here nature reigns!

I am sitting, like a bird who has fallen into a foreign land and from an open window I delight in the beauty of nature. Behold the full moon has risen too and dresses nature with a light like that of its brother. Then you will think that the stars too have begun to flicker and whisper. ... ${ }^{64}$

From his window perch, he takes in his surroundings with rapt wonderment. His description takes in the way the moon lights up the snowy peaks of far mountains of Iasamani to the east, the high and steep cliffs of mount Kuardeba to the right, to the west the peaks of Varishxeti. He moves from mountains to nearby places, to fires appearing like earth-born stars in a little village nearby, "wrapped in fresh air," the high cliffs of Qomrali, which looks out directly across to another cliff: "They look at each other with some sort of secret sorrow." Finally, his gaze returns to the city itself by moonlight, and he finishes this rapturous description so: 
Lo, the city itself. The river's reproachful muttering can be heard. From time to time the barking of dogs destroys the silence, to the right appear the ruins of an old tower; hither white houses, from whose windows can be seen laughing Tatar women; secluded by day, by night they enjoy fearless freedom.

Lo, a mullah has gone up onto the minaret and gives the call to prayer. Oh, what a pleasing voice it is! Every rise and fall of his voice, stanzas strung together like pearls strikes a man's heart strings and makes him tremble. In that voice is expressed national sentiment [nacionaluri grdznoba]. Only Orientals can feel it. This will not please the good taste of a European. .. ${ }^{65}$

In this final description, Bavreli gives full reign to a firmly sentimental, Orientalist description of Ardanuji. Here there is no attempt to use ruins as a key to decode the past; ruins are ruins, by moonlight, alongside the minaret, both are equally picturesque. Bavreli, always an ambivalent interlocutor, very unlike the later travelers, in his rapture moves into awe and wonder, typically European aesthetic responses to the Orient. But at the same time, in a move that is extremely rare for Georgians, he elides his own lyric subject position subtly into that of the Oriental: his enjoyment of the voice of the mullah's call to prayer, in which is portrayed "national sentiment" [nacionaluri grdznoba], moves him. Since it expresses "national sentiment" and therefore can only move Orientals, it will not appeal to European canons of taste, therefore, Bavreli, perched on his window in a moonlit night in Ardanuji, suggests perhaps that he himself has become, or always was, an Oriental. In some sense, this is always a position available to Georgians, who ambivalently position themselves with respect to Ottomans as Europeans and yet simultaneously oppose themselves to "real" European travelers (compare G. Qazbegi, Sano, above). But even if Georgians, then as now, treat Europe as a "shifter" in which they are now included, now excluded (on Europe as a "shifter" see Gal 1991), nevertheless, Georgians of that time, as well as now, are not similarly willing to accept the converse, that they themselves may be in some sense, in some contexts, Orientals.

This is what makes this Orientalizing moment so peculiar. His apperception of space as a Georgian, a shifting position as a traveler, himself 
an Oriental, traveling in the Orient, moves briefly from ambivalence to full identification with the Orient. And Ardanuji, a town that a moment earlier his correspondence is defined a desolate no-man's-land beyond the pale of Occidentalist circulatory civilization, is now transformed into an aestheticized Orientalist fantasy. Bavreli is similarly ambivalent, now seeing in Ardanuji a lifeless desolate place of exile from the European world of circulation, now seeing in it a place in whose autumnal moonlit nights he can lose himself momentarily in the "national sentiments" inscrutable to Europeans and pleasing only to the Oriental soul. We might ask the question, then: Who was Bavreli, a man who we know to be from a town on the borderlands of European and Ottoman Georgia? 